\title{
THE LEVEL OF EFFECTIVENESS OF POLISH LEGISLATION RELATING TO HEALTH PROTECTION AGAINST THE CONSEQUENCES OF TOBACCO USE
}

JUSTYNA ZAJDEL-CAŁKOWSKA

Lazarski University in Warsaw, Warsaw, Poland

Department of Law and Administration

\begin{abstract}
The purpose of this work is to analyze the regulatory environment for tobacco use, with particular reference to changes made in the last 10 years. An attempt was made to answer the question of the extent to which the regulatory environment has a real impact on the achievement of the objective set out in the existing legal provisions, which is to protect the health and rights of the persons concerned. An analytical method was used in the work to assess the application of legal principles. A method of analyzing the current line of jurisprudence was also used. In the process of final evaluation of public utilities, certain functional methods were used. The assessment was subjected to Polish law, within the scope of the currently binding Act on Health Protection Against the Consequences of Using Tobacco and Tobacco Products of 1995. The study states that the provisions of this Act are only a formal guarantee of protection. The liability arising from the application of its standard is illusory because the procedure for imposing penalties is ineffective. The pursuit of any property claims related to violation of the rights of related entities, as envisaged in this Act, is complicated. This does not apply to a case which is not affected by the decision. Int J Occup Med Environ Health. 2020;33(5):599-610
\end{abstract}

Key words:

tobacco, legal regulations, health protection, tobacco use, tobacco addiction, protection of non-smokers

\section{INTRODUCTION}

This article is devoted to the analysis of the regulatory environment for tobacco use, with particular reference to the changes made over the last decade. The author has attempted to answer the question of the extent to which the regulatory environment has a real impact on the achievement of the objective set out in the existing legislation, namely health protection and the protection of the rights of non-smokers. The article has analyzed the existing loopholes that prevent or significantly impede the achievement of the corresponding legal objectives.
In analyzing the situation related to the use of tobacco products, it is important to highlight the dichotomy that exists at the level of the state's interests.

On the one hand, tobacco smoking is a negative element in terms of increased health risk. This is evidenced by data showing that, in 2012, tobacco products were used by 967 million people aged $>15$ years, including $31 \%$ of men and $6 \%$ of women [1]. In Poland, tobacco products were used by every fourth citizen in 2015 (about every fifth woman and every third man) [2], while tobacco production continues to be a major agricultural industry. The current

Funding: this work was supported by Lazarski University in Warsaw.

Received: April 3, 2020. Accepted: June 16, 2020.

Corresponding author: Justyna Zajdel-Całkowska, Lazarski University in Warsaw, Department of Law and Administration, Świeradowska 43, 02-662 Warsaw, Poland (e-mail: kancelaria.prawomed@gmail.com). 
legal framework is often a component of interrelated legal and economic elements, which in theory calls for both the public health objective and the economic objective, the importance of which is underlined by the fact that, in 2016 alone, the value of the legal tobacco market in Poland was about PLN 27-29 billion [3].

While the legal and economic elements are interstated in the context of the subject matter under consideration, the overriding aim of this work is to determine whether the current legal provisions provide guarantees for the protection of public health, including the elimination of tobacco use and the minimization of the risks associated with negative health effects, which are a natural consequence of their use. The Polish-language literature has not yet analyzed whether, and to what extent, the current legislation guarantees the achievement of health and non-smoking protection objectives. Most of the publications are meant as a review of, or a comment on, the existing legislation based on the application of the classical content analysis.

The content of this work refers to the protection of health against the effects of tobacco and tobacco products, by which products intended for human consumption, consisting even partly of tobacco, including genetically modified, should be understood. The scope of the above definition is broad and covers all tobacco products, including the innovative products referred to in Article 2(11) of the Act of November 9, 1995 on Health Protection Against the Consequences of Using Tobacco and Tobacco Products (abbreviated as the Tobacco Control Act) [4]. At the same time, safeguards have been analyzed in the area of the rights of non-smokers, i.e., those who do not use tobacco products, and their exposure to the effects of their use is perceived by them as a violation of personal property, including the right to live in a smoke-free environment.

\section{METHODS}

The overriding objective of this article is to analyze Polish legislation on health protection against the consequenc- es of using tobacco and tobacco products and to assess whether its application has an impact on the achievement of the objectives set, including the protection of the rights of non-smokers. In addition, the aim of the study is to demonstrate the appropriateness of maintaining existing legislation or to indicate the need for revision. In view of the specific nature of the subject matter, the author used an analytical method to evaluate existing legislation, which was extended to include the dogmatic induction method of exegesis of the normative material. In addition, the method of analysis of the current judicature line was used. The functional method was employed in the final evaluation of the usefulness of the existing legislation. In this work, the material was Polish law. In addition, the current case-law line, the doctrine and literature on the subject matter were the source of reflection. The narrow thematic framework of this work led to a departure from the analysis of the overall health legislation against the consequences of tobacco use. The work focused on the effectiveness of the legislation, and its usefulness in minimizing health risks and protecting public health.

\section{Interpretation of existing rules}

Tobacco belongs to widely grown plants around the world, but it is not used in food production. Poland's food definition refers to the Community definition as set out in Regulation (EC) No. 178/2002 [5]. In accordance with Article 3(1) of the Act on Safety of Food and Nutrition [6], food (foodstuff) is "(...) any substance or product within the meaning of Article 2 of Regulation No. 178/2002." According to Regulation No. 178/2002 [5], food (foodstuff) is any substance or product, processed, partially processed or unprocessed, intended for human consumption or expected to be consumed. The term "food" includes beverages, chewing gum and any substances, including water, deliberately added to food during its manufacture, preparation or treatment. This definition includes water complying with the standards referred to in Article 6 of Directive 
98/83/EC [7], and without prejudice to the requirements of Directives 80/778/EEC [8] and 98/83/EC [7].

In accordance with Article 2(1) of Directive 2001/37/EEC [9], "tobacco products" mean products intended for smoking, sucking and chewing, to the extent that they are partly manufactured from tobacco, regardless of any modification. The first regulation concerning tobacco products in Poland was the Council of Ministers Regulation of October 17, 1921 [10] on Tobacco Taxation. In the following years, the Regulation [11-14] came to include, inter alia, issues related to the revision of the retail selling price of tobacco products, the classification of cigarettes of the luxury grade, and the establishment and publication of the price list of tobacco products.

Until 1974, tobacco smoking was not identified as having a negative effect on human life and health, which resulted in the mere application of legal regulations that concerned the price of tobacco products. When examining the scope of the regulation on tobacco products, it should be stressed that the wording of the Regulation of the Minister of Health and Social Welfare on the Reduction of Tobacco Smoking for Health Reasons was the first reference to both the harmful effects of tobacco smoking and the establishing of places where tobacco products could be used [15].

It should be pointed out that the very implementation of innovative legislation did not have the desired effect, including the perception of tobacco use as a social problem. The emphasis on the fact that the use of tobacco products is a public health problem was only clearly emphasized in the 1990s [16]. The ban on selling tobacco products to minors was first introduced in Poland by way of the Resolution of the Sejm of the Republic of Poland of July 26, 1991 [17]. The aim of successive legislation [4,18-20] was to tackle tobacco smoking in general, to protect health from the consequences of using tobacco and tobacco products, and to ratify the World Health Organization Framework Convention on Tobacco Control, done at Geneva on May 21,
2003 [21]. A radical change of attitude to the use of tobacco products took place in 1995, when the Tobacco Control Act came into force, which was amended in 2010 [20] and then in 2012 [22].

Given the scale of the tobacco smoking phenomenon, it has become necessary to unify the legislation on this issue and to ensure an equal level of protection for all consumers in the European Union. Directive 2014/40/EU of the European Parliament and of the Council of April 3, 2014 on the approximation of the laws, regulations and administrative provisions of the member states concerning the manufacture, presentation and sale of tobacco and related products (...) became a reality. It entered into force on May 19, 2014, and started to take effect in member states on May 20, 2016 [23]. The principles of the Directive are implemented in Poland by the specific provisions of the Act of July 22, 2016 amending the Tobacco Control Act (which entered into force on September 8, 2016) [24]. It should be emphasized that the provisions of the Directive are only a starting point for the implementation of any health guarantees and the protection of the rights of non-smokers by means of national legislation, which varies from one country to another across the European Union.

In many countries, regulations have been introduced which do not exist in Poland, which are justified to minimize exposure to tobacco smoke and substances emitted during tobacco use. In Belgium [25], educational establishments and external areas within their territory are subject to a complete ban on smoking. The partial ban on smoking concerns other places, including health care units, where zones may be designated for persons using tobacco products. In Bulgaria, legislation provides a ban on smoking in all public places, except in the case of airports where zones for the use of tobacco products may be designated. Bulgarian law not only provides for a ban on the sale of tobacco products to minors, but also a ban on the presence of persons belonging to the indicated age group at places designated for the use of tobacco products [26]. In Cyprus, 
the ban on tobacco use concerns public transport as well as cars belonging to natural persons, which include persons aged <16 years [27]. In Malta, the use of tobacco products in parks where children's play tools are installed is prohibited [28].

When analyzing issues related to the use of tobacco products in the context of the protection of public health, the State Health Inspection Act [29] is also an important regulatory act. The State Health Inspection is responsible, inter alia, for public health protection activities, and for protecting the public from adverse environmental effects and preventing disease. Under Article 4(1)(4) and (10) of the abovementioned Act, the State Health Inspection shall carry out surveillance, prevention and control activities in respect of compliance with the rules on the marketing of products which may affect human health, and with the requirements laid down in the provisions on the content of certain substances in cigarette smoke.

Under the Implementing Regulation of the Prime Minister of October 17, 2002 [31], inspection officers are entitled to impose fines in the form of a criminal mandate for offenses covered by the Tobacco Control Act of November 9, 1995 [4]. According to Article 13(1)(2) and (2) of that Act, "who (...) is the owner or manager of the premises or means of transport, (...) does not include information on the non-smoking rule, is liable to a fine of up to PLN 2000" [4]. Furthermore, "[w]ho smokes tobacco products, novel tobacco products or electronic cigarettes contrary to the provisions of Article 5 is subject to a fine of up to PLN 500" [4].

\section{RESULTS}

The introduction to the Tobacco Control Act indicated expressis verbis that it was created "to prevent dependence on tobacco and tobacco use, and to protect health from its consequence." An introduction to the Act is not a mandatory element of a legislative act with a statutory status, but only an optional content to highlight the purpose of a spe- cific regulation [31]. It should be stressed that it is clear, from the literary content of the introduction, that the purpose of the Act is to take action to prevent and minimize the use of tobacco-based addiction, rather than to take action to restrict the marketing of tobacco products, with particular emphasis on groups exposed to increased health risks. The literary significance of the rest of the introduction makes it clear that the objective of the Tobacco Control Act is to protect health from the consequences of addiction, and not to protect health from the increase in health risk as a result of the initiation or continuation of the use of tobacco products.

In accordance with Article 3 of the Tobacco Control Act [4], "[h]ealth protection against the consequences of tobacco use is achieved through health, economic and social policies, including: (1) the protection of the right of non-smokers to live in an environment free from tobacco smoke, electronic cigarettes and substances released by innovative tobacco products; (2) promoting health by promoting smoking-free lifestyles, the use of other tobacco products and electronic cigarettes; (2a) educational and information activities; (3) creating economic and legal conditions to encourage tobacco use reduction; (4) reporting on the harm caused by tobacco packaging; (5) lowering the limit values for harmful substances in tobacco products; (6) treatment and rehabilitation of tobacco-dependant persons." The case-law emphasizes that "by providing that health protection against the consequences of tobacco use is achieved through health, economic and social policies, which include the protection of the right of nonsmokers to live in a smoke-free environment, the objective of the state as expressed in the programming standard of Article 68(4) of the Constitution of the Republic of Poland will be met, ordering public authorities to prevent the adverse health effects of environmental degradation." [32]. In making the literary interpretation of Article 3 of the Tobacco Control Act, it should be assumed that the legislator's objective was to carry out health-in-genere tasks 
rather than to combat tobacco dependence and its health effects. This inconsistency introduces confusion of intent, and makes the fundamental provisions of law less transparent and their general purpose unclear. The purpose of the Tobacco Control Act, although imprecise, is pursued on the basis of Article 5(1) of that Act, which excludes from the catalogue of places intended for the use of tobacco products, inter alia, educational establishments, universities, medical practitioners, public transport stops, sports facilities, catering and leisure facilities, and public passenger transport. The provisions of the Tobacco Control Act provide for derogations from this principle in the areas where the use of tobacco products is unacceptable.

The provisions providing for exceptions in the above-mentioned areas cover gaps which allow action to be taken in contradiction with the overriding principle relating to the protection of health against tobacco smoking, and the provision of a zone free of tobacco smoke. Catering and entertainment facilities are one type of places where the use of tobacco products is prohibited. Similar prohibitions were introduced by generic means at different times to the European Union, and the country which most recently adopted the relevant regulations was Austria, where the prohibition on smoking in catering and entertainment facilities took effect on November 1, 2019 [33].

The starting point for considering derogations from the ban on tobacco use in regulated areas is the content of Article 5a(4) of the Tobacco Control Act [4], under which the owner or manager of the catering and entertainment facility with at least 2 premises for consumption may exempt from the prohibition laid down in Article 5 one enclosed smoking consumption room. It is clear from the wording of the provision that, in a catering and entertainment facility which consists of at least 2 premises intended for consumption, it is possible to separate one of them as premises where the use of tobacco products is permitted. The statement that a room intended for the use of tobacco products must be closed means that it cannot be connected to another room for consumption, including the provisional separation of its area resulting in the penetration of tobacco smoke into other rooms. Furthermore, which is not clear from the provisions of the Tobacco Control Act [4], a separate and enclosed smoking room should be a destination room, which excludes its location at the beginning or in the middle of the communication line. Otherwise, non-smokers would have to go through isolated smoking rooms [34], which would violate the right of non-smokers to live in a smokefree environment, and thus violate the conditions set out in Article 3(1) of the Tobacco Control Act.

The literature emphasizes that the content of the Tobacco Control Act is explicit, that the basic principle of the Act is the protection of non-smokers, and that the regulations contained therein should be evaluated by means of such interpretation [35]. In the author's opinion, the provisions of the Tobacco Control Act provide a starting point for the objective of protecting non-smokers, but they do not guarantee comprehensive protection in this respect. The content on the protection of the rights of non-smokers to live in an environment free from smoke, electronic cigarettes and substances released by novel tobacco products shall not apply, inter alia, to persons employed in catering and entertainment facilities whose task is to serve their users. Although the protection of workers from exposure to tobacco smoke is systematically extended [36], persons carrying out catering operations are not protected in any way although their exposure to tobacco smoke is greater [37] than the exposure of persons using the premises in question. The literature also stresses that passive exposure to tobacco smoke affects the effectiveness of workers and leads to long-term negative health effects [38].

In view of the above, it should be assumed that the provisions of the Act on the Protection of the Rights of NonSmokers safeguard the interests of this group in a piecemeal way, with de facto greater attention being paid to the protection of persons exposed occasionally (including persons using catering and entertainment facilities) than 
towards persons more exposed by reason of the amount of time they spend at the workplace. The same shall apply to personnel carrying out maintenance and cleaning tasks of the premises of the smoking rooms designated at the work facilities as premises for the use of tobacco products. Although the case-law is against the view [38,39], the designation of the Act implies a right and not an obligation for the employer. A result of the repeal of this obligation is the amendment of Section 2(2) of the Ordinance of the Minister of Labor and Social Policy of September 26, 1997 on General Health and Safety at Work, introduced by the amending Regulation of August 4, 2011 [40].

The decision of an authorized person to withdraw from the organization of smoking areas is also relevant in the context of the needs of the persons employed, who, as the studies show, report the need for education and support in the fight against nicotine dependence [41]. It should be noted that, in some European countries, regulations are in place for the safety of non-smokers at the workplace. According to German legislation, the employer may establish a general ban on smoking at the workplace in order to effectively protect non-smokers against the dangers of tobacco smoke [42]. One of the preventive measures to limit the use of tobacco products is the ban envisaged in the Tobacco Control Act on making tobacco products available to minors. In accordance with Article 6(1a) of the Tobacco Control Act [4], "in case of doubt as to the age of the purchaser of tobacco products, electronic cigarettes or spare containers, the seller may request the production of a proof of age." It should be noted that age verification is optional and depends directly on the existence of an indication of the age of the proposed acquirer of tobacco products.

Another element that needs to be clarified in the content of the Tobacco Control Act is the provision on the ban on smoking in motor vehicles. In accordance with Article $5(1)(7)$ of that Act, "smoking of tobacco products (...) in public passenger transport (...) is prohibited." Although the Act refers to a ban on smoking in the means of trans- port, it ignores the issues of smoking bans when carrying out a passenger transport service using motor vehicles not belonging to the said category. The literary wording of the provision cited above only shows that the ban on smoking of tobacco products concerns public passenger transport only.

The Act on Road Traffic of June 20, 1997 [43] refers to the ban on smoking in the course of passenger transport, but its provisions allow for far-reaching concessions in this area. In accordance with Article 63(5) of the Act on Road Traffic, "smoking or eating while driving shall be prohibited for the driver of a motor vehicle carrying a person. This does not apply to the driver of a heavy goods vehicle who transports a person in the driver's cab and the driver of a passenger car, except for a taxi." The content of the said provision requires clarification of the terms "motor vehicle" and "taxi," as defined in Article 2(32) and Article 2(43) of the Act on Road Traffic [43], respectively, meaning: "motor vehicle - a motor vehicle with the exception of mopeds and vehicles; taxi - a vehicle, suitably equipped and marked, intended for the carriage of persons of not more than 9 , including the driver, and their carry-on baggage for a fee to be determined on the basis of either a taximeter or a mobile application (...)."

It is necessary to emphasize that the prohibition envisaged in Article 63(5) of the Act on Road Traffic [43] relates only to the prohibition of smoking, and not to the use of tobacco products in general, and covers only those driving the vehicle and not all persons inside the vehicle. In addition, the prohibition does not apply to situations where the driver is transporting another person in the cabin of a truck or to a passenger vehicle that is not a taxi. The literature analysis and functional interpretation of the provision allow the prohibition expressed in its content to apply to motorcycles, motor agricultural vehicles and bicycles powered by an electric motor. It is also crucial to emphasize that the definition of the term "taxi" allows the use of tobacco products in journeys made by entities not af- 
filiated with taxi corporations but providing a passenger transport service (e.g., Uber and other entities operating under the same mechanism of action).

An area to be considered in the context of the fulfillment of the objectives set out in Article 3 of the Tobacco Control Act [4] is a ban on smoking in "other rooms available for public use," set out in Article 5(1)(11). It should be stressed that both the terms "room" and "public use" are not defined in the content of the Tobacco Control Act, which allows any interpretation that extends or limits this scope. According to Article 5(4) of that Act, the municipality states that "the municipality council may fix, by way of resolution, for the municipality other (...) places intended for public use as zones free from smoke, electronic cigarettes and substances released by the novel tobacco product" [4]. Under this provision, the municipalities maintained their legislative competence with regard to the extension of smoke-free zones to areas other than those indicated in the contents of the Tobacco Control Act for public use. The powers conferred on municipalities have been put into practice, which has increased the realization of the objectives set out in that Act [44-47].

It is argued in the literature that the term "public use" does not, however, attempt to define this specific term. In the above context, it refers to a part of the earth's surface, a part of a space in which something is located, and it is important that it is intended for public use, i.e., that it is accessible or open, permanently or temporarily, for the general public (for all), so that everyone can use this place. In other words, it is a space for shared use, which is open to the public" [48].

It should be noted that the delegation laid down in Article 5(4) of the Tobacco Control Act [4] allows the establishing of places intended for public use as tobacco-free zones solely on account of the nature of the place, premises or area, but no longer as a result of, e.g., repeated disturbances in their line of duty. Moreover, the case-law emphasizes that "the decision of the municipality council cannot regu- late once again what is already contained in the applicable law. Such a resolution, as a material violation of the law, is invalid. It is always unnecessary to include this kind of repetition, because the repeated provision is already in force, and it is also disinformation. It must be assumed that the repeated provision will be interpreted in the context of the resolution in which it appears, which may lead to a complete or partial change of the legislator's intention. The decision of the municipal authority should, therefore, not repeat the statutory provisions and should not contain provisions contrary to the law." [49-51]. In this context, it should be noted that, although municipalities have legal tools to designate zones free of tobacco products, Article 5(4) of the Tobacco Control Act does not authorize them to impose fines for non-compliance with the ban on smoking in places covered by the ban [52].

In the context of the implementation of the tasks set out in Article 3 of the Tobacco Control Act, it should be stressed that the Act does not refer to the ban on smoking in places which are not of a public nature, but can nevertheless be used by an indefinite number of users. Examples include, but are not limited to, the common parts of housing and municipal property, as well as other property owned by natural persons or legal persons. The grounds for the enforcement of the smoking ban in parts of common properties (e.g., staircases, patios, balconies) are neither defined by the Tobacco Control Act nor by the Housing Ownership Act of June 24, 1994 [53]. In accordance with Article 16(1) of the Housing Ownership Act, "[i]f the owner of the premises (...) goes in a gross or persistent manner against the applicable household order, or by his improper conduct makes the use of other premises or common property burdensome, the housing community may, by process, request the sale of premises by auction on the basis of the provisions of the Code of Civil Procedure on property enforcement." It follows from the wording of the provision cited that the housing community may take measures to sell the premises by auction in the event of persistent and burdensome in- 
fringements by the owner of the premises, whose behavior is burdensome and makes it difficult to use, e.g., parts of the common property. This provision does not provide a preventive guarantee where tobacco products are used in a burdensome manner.

Moreover, the demonstration that the use of tobacco products constitutes an obstacle to the use of parts of the common property is a delict which is hampered by the fact that the use of tobacco products in parts of the common property is not perceived by many as a common good. This is to say that the use of tobacco products in parts of the common property is not an area that could be subject to an absolute ban on smoking and, consequently, the possibility of imposing criminal sanctions.

\section{CONCLUSIONS}

Under current legislation, the use of tobacco products is legal, but activities in this area are constantly being reduced due to their negative impact on the health of both direct users and passive smokers. Despite the introduction of legislation to reduce tobacco use, in 2012-2014, the share of Poles who had ever used electronic cigarettes increased from $12.4 \%$ to $14.6 \%$ [54].

After the entry into force of the Tobacco Control Act in 1995, some of the research studies conducted in Poland indicated the emergence of a relationship between the legal restrictions imposed and the decreasing number of deaths and hospitalizations, e.g., due to myocardial infarction as a result of tobacco consumption [55]. Similar trends were pointed out in Ireland, where the acute coronary syndrome (ACS) rate fell by $12 \%$ [56] a year after the entry into force of the relevant act. In Italy, within 6 months after the entry into force of the Anti-Nicotine Act, the ACS rate fell by $6 \%$ [57], while in Scotland the decline of $17 \%$ occurred mainly among non-smokers [58]. The tightening of legislation in the Czech Republic in 2017 caused researchers to change their tobacco habits and led to a statistically significant decrease in the use of tobacco products in enclosed public spaces [59]. The literature highlights the relationship between legal restrictions, and the decline in tobacco use and its health effects [60].

The regulatory framework does not affect the restriction of tobacco use, but studies have shown that the key variable that has an impact on smoking reduction is the increase in tobacco prices. As indicated by the increase in cigarette prices by $10 \%$, the decrease in consumption in Bulgaria, Romania and Poland would be affected [61]. Given that the use of tobacco products is widespread in Poland, including in the medical profession [62], it cannot be assumed that the effective component limiting the use of tobacco products are the legal provisions relating to this issue.

The provisions of the Tobacco Control Act provide an illusory basis for the protection of health and the rights of non-smokers. The main achievement of the Act is the establishing of places where tobacco products can be used. While the legislator has mentioned the places where smoking is not allowed, it has not created a regulation that provides the basis for an effective procedure for punishing offenders. A positive initiative by the legislator was to empower municipalities to create zones free of substances generated by tobacco products, other than those mentioned in the Tobacco Control Act. However, the abovementioned legislative delegation failed to fulfill its preventive task, as the legislator abandoned the adoption of legislation in the Tobacco Control Act allowing criminal fines for the violation of the ban on tobacco use in areas designated by resolutions of municipal councils. Shortcomings in the rules are also evident as regards the bans on smoking reduction in the process of carrying out passenger transport services.

The existing rules do not introduce mechanisms to protect the rights of non-smokers in areas of public access. While exposure to tobacco products is de facto a violation of nonsmokers' personal property, the lack of a statutory ban on their use in so-called public places does not allow the assumption that such activities are illegal. 


\section{REFERENCES}

1. Bodył MR. Changes on the tobacco and tobacco wares market in Poland in years 2001-2006. Annals PAAAS. 2017;6:46-50.

2. Batorski D, Białowolski P, Czapiński J, Grabowska I, Kotowska EI, Panek T, et al. Social diagnosis 2015. Objective and subjective quality of life in Poland. Contemp Econ. 2015;9(4):8-538.

3. Poniatowski G, Glowacki K. The significance of the tobacco product manufacturing the Poland's economy [Internet]. Warsaw: Center for Social and Economic Research; 2018 [cited 2020 May 24]. Available from: https://case-research.eu/files/?id_plik $=5400$.

4. [Act of 9 November 1995 on health protection against the consequences of tobacco and tobacco use, consolidated text. J Laws 2019, item 2182]. Polish.

5. Regulation (EC) No 178/2002 of the European Parliament and of the Council of 28 January 2002 laying down the general principles and requirements of food law, establishing the European Food Safety Authority and laying down procedures in matters of food safety. Off J Laws 2002, item 31.

6. [Act on food safety and nutrition of 25 September 2006, consolidated text. J Laws 2019, item 1252]. Polish.

7. Council Directive No 98/83/EC of 3 November 1998 on the quality of water intended for human consumption. Off J Laws 1998, item 330.

8. Council Directive No 80/778/EEC of 15 July 1980 relating to the quality of water intended for human consumption. Off $\mathrm{J}$ Laws 1980, item. 229.

9. Directive No. 2001/37/EC of the European Parliament and of the Council of 5 June 2001 on the adaptation of the laws, regulations and administrative provisions of the Member States concerning the manufacture, presentation and sale of tobacco products - Commission statement. Off J Laws 2001, item 194.

10. [Ordinance of the Council of Ministers of 17 October 1921 on the extension to the voivodship of nowogrodzkie, poleskie and wolynskie and counties: bialowienski, grodzienski, and wolkowyskiof the Bialystok Voivodship, the applicable laws and regulations on the taxation of tobacco products in force in area of former Kingdom of Poland. J Laws 1921, No. 89, item 659]. Polish.

11. [The implementing regulation of the Minister ex the Prussian District of 19 November 1921 on the regulation of tobacco and tobacco wares. J Laws 1921, No. 102, item 738]. Polish.

12. [Decree of the Minister of the Treasury of 24 August 1922 on the revision of the price list for retail sale of tobacco products and on the collection of an additional monopoly fee on the stocks of these products. J Laws 1922, No. 71, item 648]. Polish.

13. [Decree of the Minister of the Treasury of 26 January 1923, amending the list of retail sales of tobacco products and collection of an additional monopoly fee on the stocks of these products. J Laws 1923, No. 12, item 79]. Polish.

14. [Decree of the Minister of the Treasury of 3 March 1923 on the new classification of cigarettes of the luxury grade made by private tobacco factories, the way in which the price list for tobacco products was established and published. J Laws 1923, No. 34, item 225]. Polish.

15. [Regulation of the Minister for Health and Social Welfare of 4 June 1974 on the reduction of smoking for health reasons. J Laws No. 22, item 135]. Polish.

16. Sukiennik J. State regulation of the tobacco market: The path of development of regulation. Academic Work of the University of Economics in Wroclaw. Institut theory pract. 2015;405:141-57.

17. [Resolution of the Parliament of the Republic of Poland of 26 July 1991 on measures to prevent and treat addiction and illnesses resulting from smoking. J Laws 1991, No. 26, item 177]. Polish.

18. [Act of 5 November 1999 on the amendment of the Law on health protection against the consequences of tobacco and tobacco use. J Laws 1999, No. 96, item 1107]. Polish.

19. [Act of 17 February 2006 on the ratification of the World Health Organization Framework Convention on Tobacco Control, done at Geneva on 21 May 2003. J Laws 2006, No. 66, item 464]. Polish. 
20. [Act of 8 April 2010 amending the Law on Health Protection against the consequences of tobacco and tobacco use and the Law on State Sanitary Inspection. J Laws 2010, No. 81, item 529]. Polish.

21. The WHO Framework Convention on Tobacco Control concluded in Geneva adopted by the World Health Assembly on 21 May 2003, entered into force on 27 February 2005, ratified by the Parliament of the Republic of Poland the Convention on 15 September 2006. Off J Laws 2007, No. 74, item 487.

22. [Act of 13 July 2012 amending the Law on the Prevention and Control of infectious diseases and infectious diseases in humans and the Law on State Sanitary Inspection. J Laws 2012, item 892]. Polish.

23. Directive No. 2014/40/EU of the European Parliament and of the Council of 3 April 2014 on the approximation of the laws, regulations and administrative provisions of the Member States concerning the manufacture, presentation and sale of tobacco and related products and repealing Directive 2001/37/EC. Off J Laws 2014, item 127.

24. [Act of 22 July 2016 amending the Law on Health Protection against the consequences of tobacco and tobacco use. J Laws 2016, item 1331]. Polish.

25. [Loi instaurant une réglementation générale relative à l'interdiction de fumerdans les lieux fermés accessibles au public et à la protection des travailleurscontre la fumée du tabac. FPS Health 2009, No. 2009024496, pp. 82139]. French.

26. World Health Organization. Health impact of tobacco control policies in line with the WHO Framework Convention on Tobacco Control (WHO FCTC), Tobbaco control fact sheet: Bulgaria [Internet]. Geneva: The Organization, 2016 [cited 2020 May 24].]. Available from: https://www. euro.who.int/_data/assets/pdf_file/0003/312591/Tobaccocontrol-fact-sheet-Bulgaria.pdf.

27. Law on the Protection of Health (Control of Smoking) of 2002. Off Gaz Rep Cypr. L. 75(I), No. 3611.

28. Subsidiary Legislation. Smoking in Public Places Regulations, S.L.315.04 (Jan 8, 2010).
29. [Act of 14 March 1985 on State Health Inspection. J Laws 2019, item 59]. Polish.

30. [Ordinance of the Prime Minister of 17 October 2002 on the conferral of fines to civil servants of the State Health authorities by means of a criminal mandate. J Laws 2014, item 282]. Polish.

31. [WSA (Provincial administrative court) judgment in Opole of 5 February 2004, II SA/Wr 318/01, CBOSA]. Polish.

32. [NSA (Chief administrative court) judgment of 10 April 2014, II OSK 2739/12, CBOSA]. Polish.

33. Burki TK. New smoking ban for restaurants and bars in Austria. Lancet Oncology. 2019;20(2):E668, https://doi.org/10. 1016/S1470-2045(19)30741-7.

34. [WSA (Provincial administrative court) judgment in Gliwice of 4 April 2013, IV SA/Gl 749/12, CBOSA]. Polish.

35. Nowak I, Nowak A. Tobacco Ban Selected legal and social aspects. HSS. 2016;23:83-103.

36. Korzeniowska E, Puchalski K. Solving the problem of smoking in the Polish enterprises during 2003-2015. Int. J Occup Med Environ Health. 2018;31(3):261-80, https://doi. org/10.13075/ijomeh.1896.01164.

37. Polańska K, Hanke W, Konieczko K. Impact of legislative measures limiting passive exposure to tobacco smoke at the workplace to the frequency of respiratory diseases among staff of catering and entertainment establishments - review of epidemiological studies. Med Pr. 2011;62(3):297-308.

38. Lipińska-Ojrzanowska A, Polańska K, Wiszniewska M, Kleniewska A, Dörre-Kolasa D, Walusiak-Skorupa J. Smoking in the workplace - legal and health aspects of passive exposure to tobacco smoke. Med Pr. 2015;66(6):827-36, https:// doi.org/10.13075/mp.5893.00357. Polish.

39. [WSA (Provincial administrative court) judgment in Lódź of 4 December 2007, ref., III Sa/Ld 541/07, Lex No. 477225]. Polish.

40. [Regulation of the Minister of Labor and Social Policy of 4 August 2011 amending the Regulation on General Health and Safety at work. J Laws 2011, No. 173, item 1034]. Polish. 
41. Korzeniowska E. The low educated employees towards health - A Polish example. In: Korzeniowska E, Puchalski K, editors. The low educated employees towards health - Challenges for health education. Łodź: Nofer Institute of Occupational Medicine; 2010. p. 116-27.

42. Ordinance of Workplaces of 12 August 2004 (Federal Law Gazette I p. 2179), last amended by Article 5 (1) of the Ordinance of 18 October 2017 (Federal Law Gazette I p. 3584); Website: Bundesamt für Justiz [Internet] [cited 2020 May 24]. Available from: https://www.gesetze-im-internet.de/englisch_arbst_ttv/englisch_arbst_ttv.html.

43. [Act of 20 June 1997 on the Law on Road Traffic. J Laws 2020, item 110]. Polish.

44. [Decision No. LIV/410/2018 of the Darlowo Municipal Council of 24 May 2018 on the establishment of the coastal area of the Western Darlowo Sea area as a smoke-free zone, electronic cigarettes vapor and substances released by the novel tobacco product, No. 2949 (Jun 22, 2018)]. Polish.

45. [Decision No. CII/2656/18 of the City Council of Krakow of 23 May 2018 on the designation of Marek Grechuta as the Cracow Park, the definition of the boundaries of the Park and the adoption of the rules of procedure of the Park]. Website: BIP [Internet] [cited 2020 May 24]. Available from: https:// www.bip.krakow.pl/?dok_id $=167 \&$ sub_dok_id $=167 \&$ sub $=$ uchwala\&query=id\%3D23372\%26typ\%3Du. Polish.

46. [Decision No. XLVI/426/18 of the City Council of Bełchatów of 29 March 2018 amending Decision No. XLII/370/13 of the City Council of Bełchatów of 28 November 2013 on the introduction of rules for the use of public facilities and facilities belonging to the City of Bełchatów, Government Gazette of Lodz Voivodeship 2018, item 2318]. Polish.

47. [Decision No. LVI/443/18 of the Municipality of Czempin of 19 March 2018 on the Rules of procedure for the use of the Rural Harbor. Government Gazette 2018, item 2925]. Polish.

48. Ostapski A. [Competencies of the Municipal Council in Defining Tobacco Smoke Free Zones] [Internet]. Samorz Teryt. 2009;19:63-9. [cited 2020 May 24]. Avaliable from: http:// bazekon.icm.edu.pl/bazekon/element/bwmeta1.element. ekon-element-000162820367. Polish

49. [Judgement of the Court of Justice of 25 June 2015, II OSK 1328/15, CBOSA]. Polish.

50. [WSA (Provincial administrative court) judgement in Olsztyn of 09 June 2015, II SA/Ol 362/15, CBOSA]. Polish.

51. [WSA (Provincial administrative court) judgement in Poznań of 03 February 2016, IV SA/Po 582/14, CBOSA]. Polish.

52. [Podlasie Voivode's supervisory Decision of 11 July 2008, No. NK.II LA.0911-139/08. LEX No. 488149]. Polish.

53. [Act on the Ownership of premises of 24 June 1994, consolidation text. J Laws 2019, item 737]. Polish.

54. Filippos FT, Laverty AA, Gerovasili V, Vardavas IC. Twoyear trends and predictors of e-cigarette use in 27 European Union member states. Tobacco Control. 2017;26(1):98-104.

55. Jankowski P, Brzozowska-Kiska M, Dębicka-Dąbrowska D, Kawecka-Jaszcz K. [The influence of ban on smoking on admissions due to acute coronary syndromes - a systematic review]. Cardiology. 2008;66(10):1107-12. Polish.

56. Janowski M, Cronin EM, Kearney PM, Kearney PP, Sullivan P, Perry JI. Impact of a national smoking ban on hospital admission for acute coronary syndromes: a longitudinal study. Coronary Heart Attack Ireland Registry (CHAIR) Working Group. Clin Cardiol. 2012;35:205-9.

57. Barone-Adessi F, Gasparrini A, Vizzini L, Merletti F, Richiardi L. Short-term effects of Italian smoking regulation on rates of hospital admission for acute myocardial infarction. Eur Heart J. 2006;27:2468-72.

58. Pell JP, Haw S, Cobbe S, Newby DE, Pell CH, Fischbacher $\mathrm{C}$, et al. Smoking ban significantly reduces acute coronary syndrome admissions. Smoke-free legislation and hospitalizations for acute coronary syndrome. N Engl J Med. 2008;359:482-91.

59. Kulhánek A, Lukavská K, Švancarová I, Fidesova H, Gabrhelim R. Changes in tobacco use patterns and motivation to quit related to the new smoke-free legislation in the Czech Republic. J Public Health (Oxf). 2019;fdz156, https://doi. org/10.1093/pubmed/fdz156. 
60. Tan CE, Glantz SA. Association between smoke-free legislation and hospitalizations for cardiac, cerebrovascular, and respiratory diseases. A meta-analysis. Circulation. 2012;126:2177-83.

61. Yeh CY, Schafferer C, Lee JM, Ho LM, Hsieh CJ. The effects of a rise in cigarette price on cigarette consumption, tobacco taxation revenues, and of smoking-related deaths in $28 \mathrm{EU}$ countries - applying threshold regression modeling. BMC Public Health. 2017;17(1):676, https://doi.org/10.1186/ s12889-017-4685-x.
62. Jankowski M, Kaleta D, Zgliszczyński WS, Grudziąż-Sękowska J, Wrześniewska-Wal I, Gujski M, et al. Cigarette and E-Cigarette Use and Smoking Cessation Practices among Physicians in Poland. Int J Environ Res Public Health. 2019; 16(19):3595, https://doi.org/10.3390/ijerph16193595.

This work is available in Open Access model and licensed under a Creative Commons Attribution-NonCommercial 3.0 Poland License - http://creativecommons.org/ licenses/by-nc/3.0/pl/deed.en. 